\title{
Analysis on Construction of Study Style in Colleges Based on Class Attendance Rate
}

\author{
Mengjie $\mathrm{He}$ \\ Xiamen University Tan Kah Kee College \\ Zhangzhou, China 363105
}

\begin{abstract}
The author takes F college of Fujian province as an example and carries out field investigation of the data of seven main factors influencing the attendance rate of college students and Pearson analysis and multiple linear regression analysis. The results show attendance rate has significant negative correlation with grade and class size, significant positive correlation with admission score, times of attendance and professional course, non-significant negative correlation with points of evaluation on teaching. Strategies and feasible paths are proposed on this basis to improve the construction of study style in colleges.
\end{abstract}

Keywords-class attendance rate; statistics; construction of study style

\section{INTRODUCTION}

The construction of study style is the foundation of colleges especially "double first-class" colleges. Colleges with rapid development in recent years face the increasing number of students internally and competition of student source and employment competition externally. It is extremely urgent to create good study style and train high quality talents. Classroom teaching is the main channel for students to acquire knowledge and finish school as well as important platform for teachers and students to communicate; class attendance rate reflects the attitudes of students toward school work, directly embodies teaching effects, teaching level of teachers and management level of colleges; so it is the core content of construction of study style in traditional colleges. Most explorations on construction of study style in colleges are qualitative research. Few quantitative researches make indepth analysis on factors influencing the construction of study style in colleges [1]. Solutions are proposed through in-depth investigation and quantitative analysis on class attendance rate and influence factors of some college (hereinafter referred to as $\mathrm{F}$ college) of Fujian province, in order to provide quantitative basis for improvement of construction of study style in colleges.

Factors influencing attendance rate are complicated. For example, foreign researches reveal the attendance rate is obviously influenced by students' learning motivation, academic record of last year, degree of economic independence, time spent in part-time job, teaching quality and nature of the course [2]. According to the existing research and teaching practice, we conclude seven factors obviously influencing the attendance rate:
- The grades of students represent learning habits of them at different periods;

- Class size may influence the difficulty of classroom management and classroom atmosphere;

- Admission scores of college students represent their learning basis and learning habits before admission;

- Required course or not;

- Professional course or not. It may influence the attitudes of teachers and students toward the course;

- The times of attendance reveal the strictness of teachers

- Points of evaluation on teaching may symbolize their acceptance degree of teachers.

Besides, from the perspective of school, factors influencing attendance rate may include educational concept and management system of colleges, campus culture, students' learning objectives, learning attitudes and value orientation. [3] However, it is difficult to quantify them because they may have indirect influence through the above main factors. It is not discussed in this paper.

\section{INVESTIGATION AND ANALYSIS}

The research team formed by three teachers and sixteen students collect first-hand data in class. SPSS 21 software is used to conduct statistic analysis of the survey data.

\section{A. Design of Survey}

1) Survey objective: Objective survey and relevant analysis on factors of students, teachers and teaching environment that influence attendance rate are conducted. Feasible solutions are proposed to provide quantitative basis and advisory opinions to improve the construction of study style in colleges.

2) Survey object: Draw fifteen classes of five majors in Grade 1 to 3 at spring semester of F College (seniors practice outside the college). Carry out field survey of attendance rate of all courses in one week.

3) Definition and description of variables: In this research, class attendance rate is regarded as dependent variable to investigate the correlation between it and seven independent 
variables like source of students (approximate admission score), grade, teaching level, classroom management, class size, possibility of required course and professional course and the correlation between these independent variables. Taking the objectivity of data into consideration, we take the points of evaluation on teaching in midterm as statistical variable embodying teaching level on the basis that the points of evaluation on teaching can reflect teaching level; take the times of attendance of teachers in class as variable embodying the strictness of classroom management. See "Table I" for details.

TABLE I. Statistical TABle OF MEAN VALUE AND STANDARD DEVIATION OF VARIABLE DISTRIBUTION

\begin{tabular}{|c|c|c|c|c|}
\hline Variables & Evaluation & Explanation & $\begin{array}{c}\text { Mean } \\
\text { value }\end{array}$ & $\begin{array}{l}\text { Standard } \\
\text { deviation }\end{array}$ \\
\hline $\begin{array}{l}\text { Attendanc } \\
\mathrm{e}^{\text {Rat })}\end{array}$ & & $\begin{array}{l}\text { (Number of } \\
\text { people present } \\
\text { in class within } \\
\text { fifteen } \\
\text { minutes/numbe } \\
\mathrm{r} \text { of students of } \\
\text { the class) } \\
\times 100 \%\end{array}$ & 84.22 & 12.663 \\
\hline \multirow{3}{*}{$\begin{array}{l}\text { Grade of } \\
\text { students } \\
\text { (Gra) }\end{array}$} & 1 & Freshman & \multirow{3}{*}{1.89} & \multirow{3}{*}{0.785} \\
\hline & 2 & Sophomore & & \\
\hline & 3 & Junior & & \\
\hline $\begin{array}{l}\text { Number of } \\
\text { students in } \\
\text { class } \\
\text { (Num) }\end{array}$ & & $\begin{array}{l}\text { Number of } \\
\text { people } \\
\text { supposed to } \\
\text { come in the } \\
\text { class }\end{array}$ & 59.31 & 26.503 \\
\hline $\begin{array}{l}\text { Approxim } \\
\text { ate } \\
\text { admission } \\
\text { score } \\
\text { (Sco) }\end{array}$ & & $\begin{array}{l}\text { Take the } \\
\text { average score } \\
\text { of enrollment } \\
\text { specialty for } \\
\text { students from } \\
\text { Fujian; } \\
\text { admission score } \\
\text { of arts is } 30 \\
\text { points higher } \\
\text { than fractional } \\
\text { line of cultural } \\
\text { course }\end{array}$ & 477.923 & 75.1121 \\
\hline \multirow{2}{*}{$\begin{array}{l}\text { Required } \\
\text { course or } \\
\text { not (Req) }\end{array}$} & 0 & Optional course & \multirow[b]{2}{*}{0.56} & \multirow[b]{2}{*}{0.498} \\
\hline & 1 & $\begin{array}{l}\text { Required } \\
\text { course }\end{array}$ & & \\
\hline \multirow{2}{*}{\begin{tabular}{lr}
\multicolumn{2}{l}{ Profession } \\
al & course \\
or & not \\
(Pro) & \\
\end{tabular}} & 0 & $\begin{array}{l}\text { Common } \\
\text { required course }\end{array}$ & \multirow{2}{*}{0.67} & \multirow{2}{*}{0.473} \\
\hline & 1 & $\begin{array}{l}\text { Professional } \\
\text { course }\end{array}$ & & \\
\hline $\begin{array}{l}\text { Times of } \\
\text { attendance } \\
\text { (Tim) }\end{array}$ & & $\begin{array}{l}\text { Times of } \\
\text { attendance in } \\
\text { one to eight } \\
\text { weeks after the } \\
\text { term begins }\end{array}$ & 3.92 & 2.447 \\
\hline $\begin{array}{l}\text { Points of } \\
\text { evaluation } \\
\text { on } \\
\text { teaching } \\
\text { (Tea) }\end{array}$ & & $\begin{array}{lr}\text { Points } & \text { of } \\
\text { evaluation } & \text { on } \\
\text { teaching } & \text { in } \\
\text { midterm } & \end{array}$ & 94.18 & 2.812 \\
\hline
\end{tabular}

\section{B. Investigation Process and Data Reduction}

The attendance rate is directly recorded by two students of the research group in class and reviewed by teachers of the research group on the scene; the times of attendance are first collected by students in the research group through interviewing students randomly before class and carry out the second and third times of collection through interviewing student representative of class. Take the average value in the three times.

This investigation involves 125 times of class; except for the data of eight times of class like class switching and incomplete data, the investigation results of 117 times of class are effective with effective rate of $93.6 \%$ after review.

\section{Analysis Model and Research Hypothesis}

On the basis of judgment on scatter diagram and curve estimation, we first analyze the relevance of dependent variable and independent variable through Pearson correlation coefficient. The model is:

$$
r=\frac{\sum(X-\bar{X})(Y-\bar{Y})}{\sqrt{\sum(X-\bar{X})^{2} \sum(Y-\bar{Y})^{2}}}=\frac{l_{X Y}}{\sqrt{l_{X X} l_{Y Y}}}
$$

Then take attendance rate as dependent variable and other factors as independent variables to carry out multiple linear regression analysis on the basis of partial correlation analysis. The model is:

$$
Y i=\beta 0+\beta 1 X 1 i+\beta 2 X 2 i+\ldots+\beta k X k i+\varepsilon i, \quad i=1,2, \ldots, n
$$

According to analysis model and existing researches at home and abroad, the following hypotheses are proposed:

Firstly, students' admission scores and grades influence attendance rate; teachers' teaching level and classroom management influence attendance rate; teaching environment like class size and nature of courses (possibility of professional course and required course) influence attendance rate.

Secondly, correlation may exist between independent variables.

\section{DATA ANALYSIS AND DISCUSSION}

\section{A. Correlation Analysis and Multiple Linear Regression Analysis}

The attendance rate relates to students, teachers and teaching environment. Correlation exists between the three factors. The correlation analysis on all factors including attendance rate helps to reveal the complicated network relation. We carry out Pearson correlation analysis on all investigation factors through curve estimation. See details in "Table II".

Take attendance rate as dependent variable to carry out multiple linear regression statistics. The inspection results of regression equation reveal: the partial correlations of possibility of required course (Req) and points of evaluation on teaching (Tea) on attendance rate are not significant ( $p>0.05)$; the determination coefficient of model $\mathrm{R} 2=0.315$; the model reaches significance $(p<0.001)$. The correlation between attendance rate and independent variables reaching significance is shown in "Table III". 
TABLE II. PEARSON CORRELATION BETWEen ALL INVESTIGATION FACTORS

\begin{tabular}{|l|l|l|l|l|l|l|l|}
\hline & \multicolumn{1}{|c|}{ Rat } & \multicolumn{1}{|c|}{ Gra } & \multicolumn{1}{c|}{ Num } & Sco & Req & Pro & Tim \\
\hline Gra & $-.295^{* *}$ & & & & & & \\
\hline Num & $-.216^{*}$ & $-.221^{*}$ & & & & & \\
\hline Sco & $.316^{* *}$ & -0.113 & 0.104 & & & & \\
\hline Req & $.259^{* *}$ & $-.425^{* *}$ & 0.06 & 0.044 & & & \\
\hline Pro & 0.031 & $.470^{* *}$ & $-.354^{* *}$ & -0.122 & $-.219^{*}$ & & \\
\hline Tim & $.220^{*}$ & $-.224^{*}$ & $-.234^{*}$ & $-.220^{*}$ & $.208^{*}$ & -0.148 & \\
\hline Tea & -0.145 & $.306^{* *}$ & $-.334^{* *}$ & $-.187^{*}$ & $-.220^{*}$ & 0.044 & 0.102 \\
\hline
\end{tabular}

TABLE III. MULTIPLE LiNEAR REgRESSION OF ATtENDANCE RATE (RAT) AND CORRELATIVE FACTORS

\begin{tabular}{|c|c|c|c|c|c|c|}
\hline & \multirow[b]{2}{*}{ Model } & \multicolumn{2}{|c|}{$\begin{array}{c}\text { Non-standardized } \\
\text { coefficients }\end{array}$} & \multirow{2}{*}{$\begin{array}{c}\text { Standa } \\
\text { rdized } \\
\text { coeffici } \\
\text { ents }\end{array}$} & \multirow[b]{2}{*}{ t } & \multirow[b]{2}{*}{ Sig. } \\
\hline & & $B$ & $\begin{array}{l}\text { Standard } \\
\text { error }\end{array}$ & & & \\
\hline \multirow[t]{6}{*}{1} & (Constant) & 64.471 & 9.166 & & 7.033 & 0 \\
\hline & Gra & -5.585 & 1.48 & -0.346 & -3.774 & 0 \\
\hline & Sco & 0.062 & 0.014 & 0.367 & 4.474 & 0 \\
\hline & Num & -0.103 & 0.043 & -0.216 & -2.426 & 0.017 \\
\hline & Tim & 1.039 & 0.457 & 0.201 & 2.275 & 0.025 \\
\hline & Pro & 4.88 & 2.403 & 0.192 & 2.031 & 0.045 \\
\hline
\end{tabular}

The multiple linear regression model of attendance rate and correlative factors is built:

Rati $=64.471-5.585 *$ Grai $+0.062 *$ Scoi$0.103 *$ Numi $+1.039 *$ Timi $+4.880 *$ Proi $+\varepsilon \mathrm{i}$

\section{B. Analysis on Correlation of Attendance Rate and Factors}

According to the analysis results of the above data, we explain the correlation of attendance rate and factors, further discuss and analyze the reasons.

1) Determination coefficient of multiple linear regression model: The significance of model $\mathrm{p}<0.001$ shows the model is effective; the determination coefficient of multiple linear regression model $\mathrm{R} 2=0.315$, namely $31.5 \%$ of the total variation can be explained by the model, indicating the model fails to accurately explain the attendance rate. The reasons are as follows: Firstly, the macroscopic analysis with class as unit in this research fails to embody microscopic differences of individuals. Secondly, the independent variable focuses on objectivity of data and fails to involve subjective factors like students' hobbies and learning motivation [4] and macro factors of school system. Thirdly, the evaluation on teaching and the attendance rate present negative correlation (see the details below) and fails to reach significance in partial correlation analysis and effectively embody teachers' teaching level in the regression model. This may be an important reason.
2) Attendance rate and evaluation of students on teaching: Non significant negative correlation

In general, the teaching level of teachers is positively correlated with the points of evaluation on teaching and the attendance rate. We assume before investigation that the points of evaluation on teaching are positively correlated with attendance rate. Unexpectedly, the results of Pearson correlation analysis show the attendance rate and the evaluation on teaching have non significant negative correlation $(\mathrm{r}=-0.145, \mathrm{p}=0.118)$. The curve estimation of them also shows similar results (see Fig. 1). Take five independent variables in "Table III" as control variables to carry out partial correlation analysis on attendance rate and points of evaluation on teaching. The nature of non significant negative correlation is not changed $(r=-0.099, p=0.299)$. The points of evaluation on teaching fail to accurately reflect the teaching level of teachers; except for the influence of the grade of students, number of students in class, source of students and possibility of required course in "Table II", according to the polarization of attendance rate in course with high points of teaching evaluation in "Fig. 1", we guess it may be caused by courses with high points of teaching evaluation and low attendance rate, low points of teaching evaluation and high attendance rate.

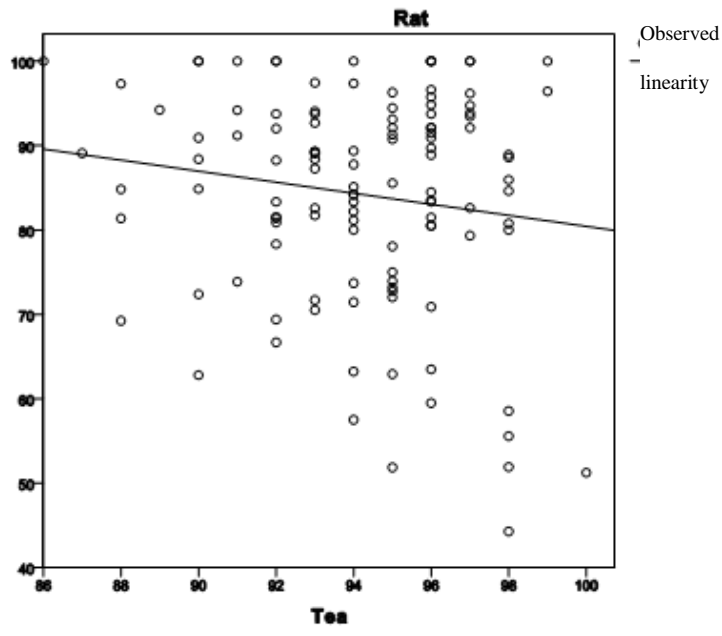

Fig. 1. Curve estimation of attendance rate (Rat) and points of evaluation on teaching (Tea) 
3) Attendance rate and grades of students: the attendance rate of freshman is higher: College teachers observe a negative correlation between the attendance rate and the grade of students; it is also verified in the investigation. The regression model reveals the attendance rate reduces $5.585 \%$ with increase of each grade. On one hand, it is because the freshman continues learning habits in junior high school and has the feeling of freshness towards college classroom; with the increase of grade, these factors are weakened and students are more independent and have higher requirements for the teaching level of teachers. They will skill the class when the courses and the teaching level of teachers are dissatisfactory. On the other hand, it is because of the collinear relationship between grade and required courses (the required courses in grade one, two and three account for $90.7 \%, 61.4 \%$ and $40 \%$ respectively). The possibility of required course with low correlation degree is excluded from the regression model. The factor of grade in the model contains the factor of possibility of required course.

4) Attendance rate and source of students: the attendance rate of students with higher scores is higher: In teaching practice with the same management condition, the attendance rate of some students is extremely high, while the attendance rate of some is unsatisfactory. The differences of attendance rate are explained from the perspective of specialty. We successfully find significant positive correlation exists between the source of students and the attendance rate. The regression model reveals the attendance rate will increase about $0.062 \%$ when the approximate admission score increases one every time. It indicates the learning foundation and habits of college students in senior high school have significant influence on college years for a long time.

5) Attendance rate with class size and possibility of professional course: The model reveals the attendance rate will decrease about $0.103 \%$ when the number of students in class increase one every time. The smaller class size contributes to more opportunities for interaction between each student and the teacher and more attention received by students and smaller possibility of mutual interference of students, the higher efficiency of teachers' classroom management, so the teaching quality and attendance rate will increase. Compared with general education curriculum, professional course has more direct effects on arousing students' interests and teaching skills of job selection and is easier to attract students' attention.

\section{CONCLUSION AND SUGGESTIONS}

\section{A. Conclusion}

According to data analysis on key variables influencing attendance rate, after excluding interaction factors between variables, we verify part of the research hypothesis:

- Significant negative correlation exists between attendance rate and grade and class size. It reveals with the increase of grade (the proportion of optional course also increases) and class size, the difficulty of management increases but the study style declines.
- Significant positive correlation exists between attendance rate and admission score, times of attendance, possibility of professional course. It reveals good source of students and strict classroom management of teachers promote study style, students pay more attention to professional course.

- Non significant negative correlation exists between attendance rate and points of evaluation on teaching. It reveals it remains to be discussed whether the points of evaluation on teaching can correctly reflect teachers' level. The phenomenon of low attendance and high points needs restraint.

\section{B. Suggestions to Improve Study Style in Colleges}

According to the above analysis results and the reality in colleges, we propose suggestions to improve attendance rate and construction of study style.

First, improve the self-management ability of students. With the popularization of higher education in our country, the learning foundation and habits of some college students have defects. They should have clear learning objectives, grasp learning methods, transfer internal and external restraints into internal self-motivation and develop good learning habits, avoid sluggishness. Besides, they should reasonably understand the relationship between professional course and non professional course, required course and option course. The provision of course of elementary guidance to subject in $\mathrm{F}$ College is beneficial attempt.

Second, improve teaching and classroom management of teachers. Classroom teaching includes the activities of teachers and students. Classroom teaching should be more vivid to attract students and the teacher should explain profound in simple terms. The ARCS model integrates attention, relevance, confidence and satisfaction in the whole learning process and let the stimulation and maintenance of learning motivation run through the learning process [4]. It has positive reference significance on classroom teaching in domestic colleges. In classroom management, college students lack learning drive; teachers should carry out efficient classroom management and do not give up students "skipping optional courses and required courses". Students will be attracted by teaching only when they sit in the classroom. We think the state with high attendance rate of students and points of evaluation on teaching at the top right corner of figure 1 is the ideal state worthy of the pursuit of colleges.

Third, build the mechanism of cooperation between teaching and ideological work. The construction of study style is systematic and progressive and requires the educational management of teachers and students. For example, course teachers can timely reflect students' class attendance, learning effects and results of periodical test to the counselor and let problem students and students with learning disabilities communicate with counselor timely to help students find the reasons. Meanwhile, the extension effect of the second classroom should be valued. College students have strong operation ability. Scientific and technological, academic and practical activities can make students have the sense of accomplishment in the competition. We can use the force of 
example to stimulate students' learning enthusiasm and promote the construction of study style.

Fourth, improve macroscopic condition of teaching. The quality of source of students has significant influence on attendance rate. High quality students are amply rewarded by F College. It contributes to the construction of study style. Furthermore, colleges need to carry out microteaching, correct the error of evaluation on teaching and reward excellent teachers and create conditions for interaction between teachers.

\section{REFERENCES}

[1] Miao Hongxia, Wang Zhihua \& Liu Qun. Research on Influencing Factors of the Study Style Construction [J], Educational research, 2016, (09): 51-58

[2] Stephen Devadoss, John Foltz. Evaluation of factors influencing student class attendance and performance [J].American Journal of Agricultural Economics, 1996, 78(3): 499-507.

[3] HAN Yan-ming. On construction of the academic atmosphere: an eternal theme of academic sustainable development [J], Journal of Higher Education, 2006, (3): 19-24

[4] Sun Dongmei, Diao Caixia. ARCS Motivation Design Model and Practical Exploration of It in Class of Colleges [J], Modern Education Science, 2011, (3): 141-144 